Original Research Article

\title{
Knowledge, attitude and practice of needle stick injury and post exposure prophylaxis in undergraduate medical students
}

\author{
Tejal C. Patel ${ }^{1}$, Tushar R. Bagle ${ }^{2 *}$, Mitesh Maurya ${ }^{3}$, Varsha Sharma ${ }^{4}$
}

${ }^{1}$ Department of Pharmacology, HBT Medical College and RNCMG Hospital, Mumbai, Maharashtra, India ${ }^{2}$ Department of Pharmacology, RGMC \& CSMH, Kalwa, Thane, Mumbai, Maharashtra, India

${ }^{3}$ Department of Clinical Pharmacology, ${ }^{4}$ Intern, Seth GSMC and KEMH, Mumbai, Maharashtra, India

Received: 24 April 2018 Accepted: 22 May 2018

*Correspondence to: Dr. Tushar R. Bagle, Email: tusharbagle21@ gmail.com

Copyright: () the author(s), publisher and licensee Medip Academy. This is an openaccess article distributed under the terms of the Creative Commons Attribution NonCommercial License, which permits unrestricted noncommercial use, distribution, and reproduction in any medium, provided the original work is properly cited.

\begin{abstract}
Background: Needle stick injury are the most common reason behind occupational blood exposure and most important source of exposure to another person's blood.

Methods: A cross-sectional observational questionnaire-based study of 450 undergraduate medical students which includes 100 from each years, Second year: Part I (II/I: Third Semester), Second year: Part II (II/III: Fifth Semester), Third Year (III: Seventh Semester), Fourth year (IV: Ninth Semester) MBBS and 50 Interns. The participation was voluntary and written consent was taken prior to enrollment. The objectives of study were explained, and validated questionnaire was administered to the students and collected in a single visit after 30-40 minutes.

Results: The average age was $21.91 \pm 2.03$ years. About 406 students were aware of disease transmitted by NSI. 189 students felt that occurrence of NSI, first person to be contacted is Medicine Physician. 208 don't know of existence of PEP. 164 felt PEP is to be given for 4 weeks. According to 138 students PEP guidelines were proposed by NACO while 101 students felt WHO. 261 students felt that most probable chance of getting NSI was in emergency ward. 363students felt that need for NSI PEP training before clinical exposure is very important. 345 felt the need for insurance of HCWs for diseases transmitted by NSI.

Conclusions: Medical students are highly vulnerable to NSI and there is need to provide adequate preventive measures, frequent training for needle stick injury and postexposure prophylaxis to all healthcare workers.
\end{abstract}

Keywords: Emergency ward, Needle, Prophylaxis, Zidovudine

\section{INTRODUCTION}

Occupational exposure is the exposure to blood borne infections that occurs while performing the duty during professional work. ${ }^{1}$ Needle stick injury (NSI) are the traumas caused by sharps like needles used for blood collection, intravenous cannulas, and different sharps used by health care workers (HCWs). ${ }^{2}$
NSI is an accidental skin penetration of stab wound with a hollow-bore needle or any sharp that is contaminated by blood or bodily fluid of another person. ${ }^{3}$ Among the injuries NSI 58\% is the common source exposure to blood and products, followed by exposure to non intact skin $22.7 \%$, contamination of mucous membrane $11.2 \%$ and cuts $(8 \%)$. In United Kingdom NSI from conventional needles and sharps is $1,00,000 \mathrm{HCW}$ per year and in United States of America it is around 6,00,000 to 
$10,00,000$ every year. ${ }^{4}$ Overall the transmission rates for Hepatitis C is 1 to $10 \%$ and Hepatitis B is 6 to $33 \%$ and the risk of seroconversion for Human Immunodeficiency Virus (HIV) is $0.31 \%{ }^{1}$

Worldwide more than $90 \%$ of the NSI occur in countries that have limited resources and the authentic data on NSI in India are scarce. ${ }^{3}$ According to a study conducted by Indian Clinical Epidemiology Network (CLEN), NSIs can be observed in $2.4 \%$ of injections given in India. In India with negligible reporting of NSI, less use of Post exposure prophylaxis (PEP) and high prevalence of sharps injuries, this led to underestimating NSI incidence. ${ }^{4,5}$ It has been observed that there are guidelines for HCW but still they take inadequate measures to prevent and treat blood borne infections following occupational exposure. The prevention of exposure, use of universal safety precautions are the most effective measure and timely PEP after needle stick exposure can be useful.

Among the HCW Interns and undergraduate medical students are at great risk of occupational exposure. ${ }^{8}$ Thus there is need to assess the knowledge, attitude and practice of NSI and PEP in interns and undergraduate medical students in a medical college and tertiary care hospital.

\section{METHODS}

A cross-sectional observational questionnaire based study of 450 undergraduate medical students which includes 100 from each years, Second year: Part I (II/I: Third Semester), Second year: Part II (II/III: Fifth Semester), Third Year (III: Seventh Semester), Fourth year (IV: Ninth Semester) MBBS and 50 Interns of medical college and tertiary hospital in a metropolitan city. Before beginning the study Institutional Ethics Committee permission (IEC No: EC/OA-49/2014) was taken. Site for the study was department of Pharmacology and Therapeutics, in medical college and tertiary care hospital. The study was conducted from January 2015 to January 2017. The participation was voluntary and written consent was taken prior to enrollment. The objectives of study were explained, and validated questionnaire was administered to the students and collected in a single visit after 30-40 minutes. Questionnaire of knowledge, attitude and practice towards NSI and PEP was prepared based on studies of NSI and PEP. Validation of the questionnaire of NSI and PEP was done by five experts from department of Pharmacology and department of Microbiology. Test-retest reliability was estimated with a subsample of 10 students by taking two interviews seven days apart. Internal consistency reliability was assessed by Cronbach's-alfa coefficient that was 0.74 . The inclusion criteria were age $>18 \mathrm{yrs}$ of age, either gender and willing to sign written inform consent form. Those who were not willing to participate or did not return or returned incompletely filled forms were excluded from the study. The questionnaire was distributed to640 students and 60 interns out of which493 undergraduate students and 57 interns returned the form. Out of these 100 students from each year, Second year (II/I: Third
Semester), Second year: Part II (II/III: Fifth Semester), Third Year (III: Seventh Semester), Fourth year (IV: Ninth Semester) MBBS and 50 Interns were included in the study.

The privacy and the confidentiality of the data was maintained throughout the study. Data was entered in MS Excel 2010, responses were coded and analysed. Descriptive statistics was expressed in terms of actual numbers, mean \pm standard deviation, frequency and percentage. $\mathrm{P}$ value $<0.05$ was considered statistically significant. Chi square test was used for comparing Categorical variables. GraphPad Prism version 5.0 software for Windows, San Diego California USA, www.graphpad.com" was used for statistical analysis for the study.

\section{RESULTS}

The average age in this study was $21.91 \pm 2.03$ (range 1828 ) years. The age in each year was statistically significant with the age group of other year $(\mathrm{P}<0.001)$. There were 208 females and 242 males. 433 students were from Urban area and 17 from rural area. 249 [55.33\%] had attended lecture on NSI and PEP. 221 (49.11\%) (II/I:12, II/III:45, III:56, IV:65, Interns:43) had undergone training on NSI and PEP whereas 236 [52.44\%] had not attended any training workshop on NSI and NSI. The age, gender and residence distribution are given in Table 1.

Table 1: The age, gender and residence distribution of students.

\begin{tabular}{|lllllll|}
\hline \multirow{2}{*}{ Academic year } & II/I & II/III & III/I & IV & Intern \\
\hline \multirow{2}{*}{ Age } & Mean & 19.70 & 20.47 & 21.36 & 22.21 & 24.03 \\
\hline \multirow{2}{*}{ Gender } & SD & 1.24 & 1.72 & 1.58 & 2.09 & 2.37 \\
\cline { 2 - 7 } & Female & 44 & 47 & 51 & 42 & 24 \\
\cline { 2 - 7 } Residence & Male & 56 & 53 & 49 & 58 & 26 \\
\cline { 2 - 7 } & Urban & 97 & 98 & 94 & 97 & 47 \\
\hline
\end{tabular}

In the occurrence of NSI, regarding the first person to be contacted, 189 [42\%] (II/I:4, II/III:36, III:62, IV:58, Interns:29) students responded by stated it to be Medicine Physician, followed by Antiretroviral Therapy center 153 [34\%] (II:59, II/III:30, III:21, IV:29, Interns:14), while 61 [13.55\%](II:11, II/III:20, III:12, IV:11, Interns:07) will inform their colleagues, 39[9\%] (II:21, II/III:11, III:5, IV:2 , Interns:0) don't know and 8 [1.77\%] feel there is no need to contact any person. The knowledge about the PEP guidelines was known to almost 268 [60\%] (II:47, II/III:55, III:57, IV:67, Interns:42) students, whereas 182 [40\%] didn't know.

About 406 [90.22\%] (II: 72, II/III:90, III:98, IV:96, Interns:50) students were aware of disease transmitted by NSI and 44 [10\%] were not aware. 292 [64.88\%] (II:20, II/III:36, III:96, IV:91, Interns:49) students knew HIV, Hepatitis B and Hepatitis C were transmitted by NSI, 143 [31.77\%] (II:77, II/III:60, III:2, IV:3, Interns:1) felt that 
only HIV can be transmitted, 7 felt only Hepatitis B, 4 felt only Hepatitis C while 4 don't know about diseases that are transmitted by NSI. 388 [86.22\%] (II:78, II/III:87, III:91, IV:86, Interns:44) felt PEP is very important after getting NSI, 53 felt it is important, 7 felt slightly important, 2 not important, while there were none that feel it is not important at all. 415 [92.22\%] students irrespective of their academic year were aware of the disease transmitted by NSI and stated that PEP is important following NSI.

All the students felt NSI and PEP were equally important There was no statistically significant difference in the importance $(p=0.7146)$. About the organization that has proposed PEP, 101[22.44\%] students felt it was World Health Orgnization, 52 [11.55\%] felt Medical Council of India, 24 [5.33\%] the Central Drugs Standard Control Organization, 138 [30.66\%] (II:13, II/III:22, III:31, IV:44, Interns:28) National Aids Control Organization (NACO), 135 (II:39, II/III:35, III:38, IV:19, Interns:4) don't know. NACO was rightly identified by the students and was statistically significant $(\mathrm{p}<0.001)$. Overall, interns had better knowledge on the organization that proposed the PEP.

Almost 347 [77.11\%] (II:74, II/III:66, III:79, IV:81, Interns:47 [94\%]) students felt PEP is not effective after 72 hours, while 103 [23\%] felt it is effective, this was statistically significant $(\mathrm{P}=0.0015)$. More than $50 \%$ of $2^{\text {nd }}$ and $3^{\text {rd }}$ year students and $94 \%$ of interns responded correctly that PEP is ineffective after $72 \mathrm{hrs}$. The medications used for PEP among 450 students, 86 [19.11\%] felt only Zidovudine, 75 [16.66\%] felt Lamivudine, 62 [13.77\%] felt Nelfinavir, 36 [8\%] felt Nevirapine, 41 [9.11\%] felt combination should be given, 150 [33.33\%] (II: 55, II/III: 56, III: 15, IV: 18, Interns:6) didn't know about drug combinations for PEP. Time to commence PEP after needle stick injury is given in Table 2.

Table 2: Time to commence PEP after needle stick injury.

\begin{tabular}{|llllll|}
\hline Academic year & II/I & IJ/III & III/I & IV & Intern \\
\hline Within 2 hour & 45 & 66 & 51 & 61 & 40 \\
\hline Within 6 hours & 28 & 9 & 20 & 13 & 6 \\
\hline After 72 hours & 4 & 6 & 11 & 8 & 0 \\
\hline After HIV status & 2 & 1 & 3 & 5 & 0 \\
\hline Don't Know & 21 & 18 & 15 & 13 & 4 \\
\hline
\end{tabular}

Regarding the time duration for which PEP is to be taken,164 [36.44\%] (II:17, II/III:29, III:37, IV:45, Interns:36) felt it is to be given 4 weeks, 79 [17.55\%] felt for 1 week, 71 [15.77\%] for 6 months, 4 for lifetime, 132 [29.33\%] (II:55, II/III:26, III:30, IV:20, Interns:1) did not know the time duration for which PEP is to be taken. Out of 450, $244(54.22 \%)$ felt Hepatitis B vaccine is given for prophylaxis and exposure, 150 [33.33\%] only for prophylaxis, 16 [3.55\%] only after exposure and 40 [8.88\%] don't know. After NSI, timing to do HIV-Elisa test, 151 students felt it should be done immediately, 51 after 6 weeks, 28 after 3 months, 23 after 6 months, 106 felt it has to be done in all the given periods, 91 don't know. Students view on disposal of used needle is given in Table 3.

Table 3: Disposal of used needle.

\begin{tabular}{|llllll|}
\hline Academic year & II/I & II/III & III/I & IV & Intern \\
\hline $\begin{array}{l}\text { In puncture } \\
\text { resistant } \\
\text { container with } \\
\text { disinfectant }\end{array}$ & 56 & 39 & 48 & 55 & 32 \\
\hline $\begin{array}{l}\text { Destroying the } \\
\text { needle by } \\
\text { needle destroyer }\end{array}$ & 30 & 35 & 46 & 21 & 14 \\
\hline $\begin{array}{l}\text { Bend the needle } \\
\text { and throw in } \\
\text { dustbin }\end{array}$ & 5 & 4 & 3 & 16 & 1 \\
\hline $\begin{array}{l}\text { Directly in the } \\
\text { dustbin }\end{array}$ & 2 & 3 & 2 & 7 & 2 \\
\hline $\begin{array}{l}\text { By recapping } \\
\text { the used needle }\end{array}$ & 7 & 19 & 1 & 1 & 1 \\
\hline
\end{tabular}

About standard procedure for reporting NSI, 392 [87.11\%] students knew that institute has standard procedure while 58 [12.88\%] (II:23, II/III:16, III:9, IV:9, Interns:1) didn't know about it. Out of 450, 73 [16.22\%] (II:1, II/III:17, III:15, IV:19, Interns:21) witnessed NSI, 377 has not witnessed NSI. The most probable chance of getting NSI 281[62.44\%] (II:51, II/III:59, III:64, IV:62, Interns:45) felt it was after recapping the used needle, 87 [19.33\%] after handling sharp instruments, 54 [12\%] after withdrawing needle, 28 [6.22\%] on disposal. Reasons for not using post exposure prophylaxis for HIV is given in Table 4. Students felt that most probable chance of getting NSI was in emergency ward $261(58 \%), 79$ [17.55\%] felt it was in ward, 21 [4.66\%] in ICCU, 30 [6.66\%] in OT and 59 [13.11\%] in other departments which included labour room, injection room in minor procedures etc.

\section{Table 4: Reasons for not using post exposure prophylaxis for HIV.}

\begin{tabular}{|llll|ll|}
\hline Academic year & II/ & II/II & III/I & IV & Intern \\
\hline $\begin{array}{l}\text { Don't know of } \\
\text { existence of PEP }\end{array}$ & 58 & 45 & 55 & 45 & 5 \\
\hline $\begin{array}{l}\text { Side effects of } \\
\text { drugs }\end{array}$ & 13 & 21 & 17 & 38 & 40 \\
\hline $\begin{array}{l}\text { Fear of HIV } \\
\text { result }\end{array}$ & 17 & 10 & 10 & 4 & 0 \\
\hline $\begin{array}{l}\text { Not necessary to } \\
\text { take PEP }\end{array}$ & 5 & 7 & 4 & 4 & 3 \\
\hline $\begin{array}{l}\text { High cost of the } \\
\text { drugs }\end{array}$ & 7 & 17 & 14 & 9 & 2 \\
\hline
\end{tabular}

After exposure to human immunodeficiency virus (HIV), the reasons given by $\mathrm{HCW}$ for not using PEP is given in table 4 . The most common factors that contribute to NSI 
are $223(49.55 \%)$ due to lack of time, 104 (23.11\%) due to lack of assistance, 87 [19.33\%] due to fatigue, 36 felt NSI could not be prevented. Almost 362 [80.44\%] felt that PEP can reduce likelihood of HIV. Immediate measures taken after accidental needle stick injury is given in Table 5 .

Table 5: Immediate measures taken after accidental needle stick injury.

\begin{tabular}{|llllll|}
\hline Academic year & II/I & II/III & III/I & IV & Intern \\
\hline $\begin{array}{l}\text { Use antiseptics } \\
\text { like Betadine }\end{array}$ & 14 & 23 & 24 & 35 & 10 \\
\hline $\begin{array}{l}\text { Promote active } \\
\text { bleeding by } \\
\text { squeezing the site } \\
\text { of injury }\end{array}$ & 22 & 16 & 29 & 24 & 1 \\
\hline $\begin{array}{l}\text { Put the prick } \\
\text { finger in the } \\
\text { mouth }\end{array}$ & 11 & 4 & 6 & 3 & 2 \\
\hline $\begin{array}{l}\text { Wash with soap } \\
\text { and water only }\end{array}$ & 52 & 52 & 39 & 35 & 37 \\
\hline Nothing & 1 & 5 & 2 & 3 & 0 \\
\hline
\end{tabular}

Factors that determine the risk of infection 334 (74.22\%) students felt it was nature of exposure, 57 [12.66\%] felt it was status of the source patient, 42 [9.33\%] felt it depends on the size of the needle while 17 [3.77\%] felt it was the age of the patient. Students felt that need for NSI PEP training before clinical exposure is Very Important 363 [80.67\%], Important 63 [14\%], Slightly Important 10, Not Important 9, Not important at all 5. All the students feel NSI and PEP training important before clinical exposure $(\mathrm{p}=0.1506)$. Immediate cleaning measures taken after accidental needle stick injury at the site of NSI is given in Table 6.

\section{Table 6: Cleaning measure at the site of NSI taken after accidental needle stick injury.}

\begin{tabular}{|llllll|}
\hline Academic year & II/I & II/III & II/I & IV & Intern \\
\hline $\begin{array}{l}\text { Wash with soap } \\
\text { and water }\end{array}$ & 12 & 4 & 17 & 66 & 1 \\
\hline $\begin{array}{l}\text { Wash with water, } \\
\text { soap and spirit }\end{array}$ & 21 & 5 & 16 & 55 & 3 \\
\hline $\begin{array}{l}\text { Wash with water, } \\
\text { soap, spirit and } \\
\text { squeeze the } \\
\text { affected part }\end{array}$ & 13 & 7 & 10 & 64 & 6 \\
\hline $\begin{array}{l}\text { Wash with water, } \\
\text { soap and take } \\
\text { post exposure } \\
\text { prophylaxis }\end{array}$ & 16 & 15 & 19 & 47 & 3 \\
\hline $\begin{array}{l}\text { No need to wash, } \\
\text { take only post } \\
\text { exposure } \\
\text { prophylaxis }\end{array}$ & 7 & 2 & 3 & 38 & 0 \\
\hline
\end{tabular}

When asked about the frequency of gloves used during phlebotomy, 221[49.11\%] (II:35, II/III:49, III:51, IV:53,
Interns:33) students stated that they used gloves all the time, 92 only in high risk patients, 97 occasionally and 40 not at all. The frequency of using gloves by HCW all the time was statistically significant $(\mathrm{p}=0.0061)$. The factors that are responsible for NSI are given in Table 7 . The possible contributory factor for needle stick injury according to students was high patient load 224 (49.78\%), Health care workers fault 52, Casual approach towards needle stick injury 137, Patients fault 37. 349 [77.55\%] Students felt that consent of the source patient should be taken before testing the blood. Almost, 318 (70.66\%) students felt there is needing to frequently do blood tests for various infections transmitted through accidental needle stick injury. $276(61.33 \%)$ students had taken hepatitis $\mathrm{B}$ vaccination. 345 students $(76.66 \%)$ felt the need for insurance of HCWs for diseases transmitted by NSI.

Table 7: Determinants that are responsible for needle stick injury.

\begin{tabular}{|llllll|}
\hline $\begin{array}{l}\text { Academic year } \\
\text { Excessive use of }\end{array}$ & II/ & II/III & III/ & IV & Intern \\
$\begin{array}{l}\text { injections and } \\
\text { unnecessary sharps }\end{array}$ & 31 & 2 & 0 & 1 & 1 \\
\hline $\begin{array}{l}\text { Lack of sharp } \\
\text { disposal containers, } \\
\text { disposable syringes }\end{array}$ & 24 & 1 & 3 & 2 & 0 \\
\hline $\begin{array}{l}\text { Lack of access to } \\
\text { and failure to use } \\
\text { sharp containers }\end{array}$ & 19 & 37 & 25 & 25 & 13 \\
\hline $\begin{array}{l}\text { Inadequate or short } \\
\text { staff }\end{array}$ & 13 & 31 & 21 & 31 & 10 \\
\hline $\begin{array}{l}\text { After use } \\
\text { Recapping the } \\
\text { needles }\end{array}$ & 10 & 26 & 23 & 26 & 3 \\
\hline $\begin{array}{l}\text { Lack of innovative } \\
\text { engineering } \\
\text { methods such as } \\
\text { safer needle } \\
\text { devices }\end{array}$ & 1 & 1 & 1 & 0 & 11 \\
\hline $\begin{array}{l}\text { Passing } \\
\text { instruments from } \\
\text { hand to hand in the } \\
\text { operation theatre }\end{array}$ & 1 & 0 & 20 & 13 & 0 \\
$\begin{array}{l}\text { Lack of awareness } \\
\text { and lack of training }\end{array}$ & 1 & 2 & 7 & 2 & 12 \\
\hline
\end{tabular}

\section{DISCUSSION}

All categories of HCW within the hospital should be informed about how to protect themselves against potential blood-borne infections (HBV, HCV, HIV) and other pathogens. In the incident of NSI, regarding the first person to be contacted, $42 \%$ of students in this study stated physician, followed by antiretroviral therapy (ART) center by $34 \%, 9 \%$ did not know that NSI needs to be reported whereas only $2 \%$ do not feel the need to contact. This finding was to some extent better than the findings of a 
study conducted on 272 medical students and interns by Al-Dabbas, where $28 \%$ students didn't know that there is need to report NSI and they also did not know where and to whom to report. In another study by Swe, $81 \%$ participants were of opinion that after an NSI, reporting the same is not useful. ${ }^{9,10}$ Similarly results were seen in study by Siddique $29 \%$ students had experienced NSI but none reported. ${ }^{11}$ Around $55 \%$ students did not report the NSI in studies conducted by Gandha and Saleem. ${ }^{12,13}$ This observation on reporting of NSI from various studies therefore reveals that the HCWs including medical students were unaware of the fact that every NSI needs reporting.

Almost $60 \%$ of students in this study had knowledge about the PEP guidelines, which was comparable to the findings stated by Kasat in a study on dental students and AlDabbas in a study conducted on interns. ${ }^{9.14}$ Poor knowledge of healthcare workers on the PEP guidelines has been mentioned in few studies carried out previously. ${ }^{11,12,15,16}$ In a study by Aminde though mentioned that $27 \%$ of medical students indeed knew the ideal PEP guidelines. ${ }^{16}$ This observation was further supported by the findings of Saleem which observed that $33 \%$ postgraduate students and $19 \%$ doctors had exact knowledge on PEP and also the time of initiation of PEP. ${ }^{12,13}$ These findings perhaps implies a positive correlation between the years of clinical experience with the knowledge on PEP guidelines.

Majority of students (90\%) irrespective of their academic year in this study were well aware of the diseases transmitted by NSI. Regarding the correct information on the time duration within which the PEP is effective was answered correctly by $77 \%$ of students. This was encouraging finding compared to the findings of other studies such as Al-Dabbas which mentions $49 \%$ interns and Cervini which mentions only 6 of 157 medical students, and Gandha that cited $33 \%$ post graduate students having the knowledge about PEP with respect to the time duration. ${ }^{9,12,17}$

In this study students had failed to answer the question pertaining to names of the drugs used in PEP particularly the combination of anti-HIV drugs used for prophylaxis and the time duration for which it needs to be taken. Poor knowledge regarding the drugs to be used in PEP was one of the important findings of few other studies too. ${ }^{2,11,14}$ In contrast to our finding, a study carried out by Aminde stated that $34 \%$ of their students knew the ideal regimen of 3 drugs as per their country guidelines for HIV PEP. ${ }^{16}$

When asked about the reasons for not using the PEP against HIV, approximately 50\% students replied that they were unaware of the existence of PEP whereas many interns replied the fear of the side effects that discouraged them from receiving PEP. Also students had no idea about the time to do HIV-ELISA test following a NSI. In this study $80 \%$ replied that prior to clinical exposure, training in PEP is very important. Similar views were cited by Al-
Dabbas as well. ${ }^{9}$ These findings reflect that adequate information about the PEP regimen needs to be conveyed to the students from time to time during their academic years, particularly before starting internship.

When inquired about the practices for disposal of used needles, approximately 50\% students replied that they disposed the used needle by throwing it in the puncture resistant container with disinfectant and around 30-40\% used needle destroyer for discarding the used needle. Recapping has been mentioned as the major cause for NSI and second reason after blood collection as stated by Murlidhar, Ashat, Saleem. ${ }^{2,13,15}$

$58 \%$ students stated emergency ward had maximum chance to get NSI. Students have given various reasons for getting the NSI, such as $50 \%$ of our students felt it happens due to lack of time, lack of assistance, fatigue. In addition, a study by Saleem. ${ }^{13}$ mentioned other reasons such as lack of skill, lack of awareness, and carelessness for getting NSI.

On enquiring regarding the immediate measures taken following NSI, $48 \%$ students stated as washing with soap and water, similar to the findings cited in other similar studies. ${ }^{2,11,14,16}$

When asked about the factors that contributes to NSI, almost 50\% students opined that it is the high patient load whereas $30 \%$ students answered it as the casual approach of the healthcare workers towards the NSI. When asked about Hepatitis B vaccination, it was realized that only $60 \%$ of our students were vaccinated against Hepatitis B virus which was below par in as compared to $90 \%$ of the medical students in study by Saleem. ${ }^{13}$ In addition, three forth of our students too felt the need for insurance of all healthcare workers for diseases transmitted by NSI. Our study on the knowledge, attitude and practices of undergraduate students and interns with regards to NSI and PEP revealed that though the students had adequate knowledge on NSI but majority of them were unaware that it needs to be reported. These findings suggest the need for organizing a sensitizing sessions on the course of action to be taken following a NSI and also updating students about the PEP. Awareness regarding NSI and PEP can be further reiterated by displaying charts with the information related to steps to be followed in case of NSI and PEP.

All categories of HCW within the hospital should be informed about how to protect themselves against potential blood-borne infections and other pathogens. There is need of Hospital infection control committee that can conduct regular trainings for universal precaution and post-exposure prophylaxis implementation. Also, there should be provision of Insurance for HCW suffering from NSI.

Funding: No funding sources Conflict of interest: None declared 
Ethical approval: The study was approved by the Institutional Ethics Committee (IEC No: EC/OA-49/2014)

\section{REFERENCES}

1. National Aids Control Organization. Ministry of Health and Family Welfare. Antiretroviral Therapy Guidelines for HIV-Infected Adults and Adolescents Including Post-Exposure Prophylaxis. [homepage on internet]. 2013. [cited on 2017 Oct 21]. Available at: http://naco.gov.in/sites/default/files/Antiretroviral\%2 0Therapy $\% 20$ Guidelines $\% 20$ for $\% 20 \mathrm{HIV}$ Infected $\% 20$ Adults $\% 20$ and $\% 20$ Adolescents $\% 20$ May \%202013\%281\%29_0.pdf

2. Muralidhar S, Singh PK, Jain RK, Malhotra M, Bal M. Needle stick injuries among health Careworkers in a tertiary care hospital of India. Indian $\mathbf{J}$ Med Res. 2010;131:405-10.

3. Centre for Disease Control and Prevention. Sexually transmitted diseases treatment guidelines. 2015. [Last accessed on 2017 Oct 22]. Available at: https://www.cdc.gov/mmwr/pdf/rr/rr6403.pdf

4. Lee KL, Hassim N. Implication of the Prevalence of Needlestick Injuries in a General Hospital in Malaysia and Its Risk in Clinical Practice. Environmental Health and Preventive Medicine. 2005;10:33-41.

5. Matsubara C, Sakisaka K, Ali M. Prevalence and Risk Factors of Needle Stick and Sharp Injury among Tertiary Hospital Workers, Vientiane, Lao PDR. J of Occu Heal. 2017;59(6):581-5.

6. Sudhir, Deepa K, Ashok NC, Murali D. A Study to Assess Knowledge And Practice In Relation To Universal Precautions And Awareness Regarding Post-Exposure Prophylaxis For HIV Among Interns Of A Medical College In Mysore District, South India. Int J of Rec Scie Resea. 2013;4(10):1554-7.

7. Anvitha K, Koppad R, Santosh Kumar A, Prashanth HL. A Cross Sectional Study on Awareness Regarding Pre (Standard Precautions) And Post Exposure Prophylaxis Of HIV / AIDS Among Heathcare Providers Of Mcgann Teaching Hospital, Shivamogga, Karnataka. Int J Med Pharm Sci. 2014;04:09-14.

8. Sarah OA, Akinsegun AA, Charles JE, Adewumi A, Majeed O. Knowledge, Attitude and Practices of HIV Post Exposure Prophylaxis Amongst Health Workers in Lagos University Teaching Hospital. Occup Med Health Aff. 2014;2(1):1-3.
9. Al-Dabbas M, AbuRmeileh NME. Needlestick Injury Among Interns and Medical Students in The Occupied Palestinian Territory.EMHJ. 2012;18(7):700-6.

10. Swe KMM, Somrongthong R, Bhardwaj A, Abas ABL. Needle Sticks Injury Among Medical Students During Clinical Training, Malaysia. International Journal of Collaborative Research on Internal Medicine and Public Health. 2014;6(5):121-31.

11. Siddique K, Mirza S, Tauqir SF, Anwar I, Malik AZ. Knowledge Attitude and Practices Regarding Needle Stick Injuries Amongst Healthcare Providers. Pakistan Journal of Surgery. 2008;24(4):243-8.

12. Gandha KM, Dhaduk KM, Yadav SB. A Study to Assess Knowledge Of Health Care Workers In Relation To Post Exposure Prophylaxis In HIV/AIDS, In Jamnagar District, India.JPBMS. 2012;23(23):1-3.

13. Saleem T, Khalid U, Ishaque S, Zafar A. Knowledge, Attitudes and Practices Of Medical Students Regarding Needle Stick Injuries. J Pak Med Assoc. 2010;60(2):151-6.

14. Kasat VO, Saluja H, Ladda R, Sachdeva S, Somasundaram KV, Gupta A. Knowledge, Attitude And Practices Toward Post Exposure Prophylaxis For Human Immunodeficiency Virus Among Dental Students In India. Ann Med Health Sci Res. 2014;4:543-8.

15. Ashat M, Bhatia V, Puri S, Thakare M, Koushal V. Needle Stick Injury and HIV Risk Among Health Care Workers In North India. Indian $\mathbf{J}$ Med Sci. 2011;65:371-8.

16. Aminde LN, Takah NF, Noubiap JJN, Tindong M, Ngwasin C, Jingi AM. Awareness and Low Uptake Of Post Exposure Prophylaxis For HIV Among Clinical Medical Students In A High Endemicity Setting. BMC Public Health. 2015;15(1104):1-9.

17. Cervini P, Bell C. Needlestick Injury and Inadequate Post-Exposure Practice in Medical Students. Niger Med J. 2013;54(6):365-70.

Cite this article as: Patel TC, Bagle TR, Maurya M, Sharma V. Knowledge, attitude and practice of needle stick injury and post exposure prophylaxis in undergraduate medical students. Int J Basic Clin Pharmacol 2018;7:1297-302. 